\title{
Low temperature stress and changes in the lignin content and composition in Eucalyptus globulus
}

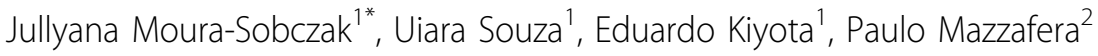 \\ From IUFRO Tree Biotechnology Conference 2011: From Genomes to Integration and Delivery \\ Arraial d'Ajuda, Bahia, Brazil. 26 June - 2 July 2011
}

It is known that many abiotic stresses, such as mineral deficiency, drought, UV-B radiation, wind and low temperatures, alter the quantity and composition of lignin in several species [1]. The aim of this work was to verify if the cold stress may cause changes in the quantity and composition of lignin in E. globulus. Additionally, we analyzed whether these changes can also be beneficial from the industrial point of view, that is, if this would allow a better extractability of lignin in this species, which is a desirable feature in the manufacture of paper. During the day, all plants were kept in a greenhouse at room temperature but at night, half of plants was transferred to growth chamber at $12{ }^{\circ} \mathrm{C}$ and half to $25{ }^{\circ} \mathrm{C}$. These conditions were kept during 20 days. The stems of plants from the two groups were collected and analyzed for total lignin with thioglycolic acid [2] and submitted to thioacidolysis and GC-MS analysis for the determination of the monomeric lignin composition [3]. Part of the material was used to determine the digestibility of cellulose [4].

It was observed that cold reduced the accumulation of lignin in E. globulus. GC-MS analysis showed that the proportion of the $S / G$ was reduced in plants subjected to low temperatures and it was also observed a lower digestibility of cellulose in these plants, indicating that this lignin could be more difficult to be removed in industrial processes of papermaking.

These results have been related with gene expression studies for the enzymes of the lignin biosynthesis pathway and may contribute to understand the processes controlling lignin deposition in eucalyptus.

\footnotetext{
* Correspondence: jucbio@gmail.com

11. Departamento de Fisiologia Vegetal. Instituto de Biologia - Unicamp. CEP: 13083-970 Campinas, SP, Brazil

Full list of author information is available at the end of the article
}

\section{Author details}

11. Departamento de Fisiologia Vegetal. Instituto de Biologia - Unicamp. CEP: 13083-970 Campinas, SP, Brazil. ${ }^{2} 4$. Departamento de Fisiologia Vegetal. Instituto de Biologia - Unicamp. CEP: 13083-970 Campinas, SP, Brazil.

Published: 13 September 2011

\section{References}

1. Moura JCMS, Bonine CAV, Viana JOF, Dornelas MC, Mazzafera P: Abiotic and Biotic Stresses and Changes in the Lignin Content and Composition in Plants. J Integr Plant Biol 2010, 52:360-376.

2. Lange BM, Lapierre C, Sandermann HJR: Elicitor-induced spruce stress lignin. Plant Physiol 1995, 108:1277-1287.

3. Rolando C, Monties B, Lapierre C: Thioacidolysis. In Methods in Lignin Chemistry. Berlin: Springer-Verlag;Lin S, Dence C 1992:334-349.

4. Chen F, Dixon RA: Lignin modification improves fermentable sugar yields for biofuel production. Nat Biotechnol 2007, 25:759-761.

doi:10.1186/1753-6561-5-S7-P102

Cite this article as: Moura-Sobczak et al:: Low temperature stress and changes in the lignin content and composition in Eucalyptus globulus. BMC Proceedings 2011 5(Suppl 7):P102.

Submit your next manuscript to BioMed Central and take full advantage of:

- Convenient online submission

- Thorough peer review

- No space constraints or color figure charges

- Immediate publication on acceptance

- Inclusion in PubMed, CAS, Scopus and Google Scholar

- Research which is freely available for redistribution

Submit your manuscript at www.biomedcentral.com/submit

\section{() Biomed Central}

\section{Biomed Central}

